\title{
Pădurile composesorale din Bucovina
}

\author{
V.C. Filip \\ Oficiul Cooperației Cernăuți
}

În Revista Pădurilor numărul 4 (XLII) din aprilie 1930 s-a publicat articolul cu tema: „Pădurile composesorale din Bucovina" ca un semnal de alarmă tras pentru salvarea pădurilor bucovinene supuse unei imense presiuni din partea proprietarilor și unui haos legislativ confuz.

După trecerea în revistă a istoricului proprietății forestiere din această provincie, utilizând izvoare scrise valoroase, cunoscute în istoriografia silvică, autorul explică modul de constituire a pădurilor composesorale după o administrație destul de exigentă și bazată pe o legislație clară și fermă precum aceea care reglementa gestionarea pădurilor Fondului Bisericesc din Bucovina. (În acest sens se reamintește de „Orândueala de pădure din Bucovina” dată de împăratul Iosif al II-lea în 1786). Tocmai având în vedere apărarea și consolidarea dreptului sfânt de proprietate, ca urmare a reformelor induse de revoluția de la 1848, Fondul Bisericesc a cedat 80.500 ha și a început în 1853 răscumpărarea drepturilor de servitute (păşunat, lemn de foc, lemn de construcție) ce a însemnat cedarea a încă 85.876 ha și o sumă importantă de numerar. Fondul bisericesc a dorit astfel să elimine orice fel de ingerință în proprietatea sa. În același timp și administrarea și exploatarea pădurilor composesorale fiind reglementată în viziunea apărării și conservării lor, pentru că „Toate legile forestiere austriace cuprind dispozițiuni pentru buna administrare a acestor păduri și impiedicarea devastării lor." Introducerea cărții funciare în Bucovina (1874) a însemnat un nou pas spre clarificarea proprietății forestiere.

Din păcate o altă atitudine asupra pădurii avea să se instituie după trecerea de la legislația austriacă la legislația românească în urma Marii Uniri. Reforma agrară din 1921 (Legea 3608/1921 pentru reforma agrară din Bucovina) a constitut imboldul pentru ieșirea din indiviziune în numeroase comune pe care autorul le aduce ca exemplu, constatând că: „după atâția ani de la alipirea Bucovinei la patria mumă suntem nevoiți să asistăm cu durere la destrămarea acestor păduri ce au constituit drepturi câștigate de strămoșii devălmașilor de astăzi”

Dorind să argumenteze degringolada instalată în pădurile composesorale autorul articolului prezintă o analiză documentată a cauzelor ca au dus la ieșirea din indiviziune, a ineficacității legislației românești precum și a mulțimii de profitori - pescuitori în apele tulburi ale lipsei de reglementare. Pentru stoparea jafului, se considera la vremea aceea că soluția trebuie să vină din partea legiuitorului, propunându-se câteva măsuri.

Citind acest articol în mod inevitabil lectorul contemporan va fi împins către o paralelă cu situația creată de astă dată în toate pădurile României, când legile 18/1991, 1/2000, 247/2005 nu au reușit să evite devastarea prin tăieri ilegale a peste 500.000 ha, probând atât incapacitatea legiuitorului cât și a celor plătiți să apere pădurea, de a face realizabilă această misiune. Totodată cititorul este pus în fața unei alte întrebări: Nu cumva au funcționat aceleași interese (poate altele și mai mari și mai veroase) acum ca și în urmă cu aproape 100 de ani? După cum se poate constata încă o dată, istoria se repetă. Și de fiecare dată nu la modul cel mai favorabil pentru pădure. La fiecare cotitură a istoriei în binecuvântatul spațiu carpato - danubiano - pontic, cei care au plătit au fost țăranul și pădurea.

Radu Leontie Cenușă

Universitatea „Ştefan cel Mare” din Suceava, Facultatea de Silvicultură

Din tot cuprinsul pământului românesc, regiunea cea mai păduroasă o formează Bucovina, cu $44,01 \%$ păduri din suprafața sa totală.

Dacă sub ocupația austriacă (1774-1918) s'au tăiat de către societățile străine cele mai frumoase masive forestiere ale Bucovinei, as- tăzi, pădurile stăpânite în devălmăşie - pădurile composesorale - se împart și se exploatează cu o iuțeală uimitoare.

Deși chestiunea eșirii din indiviziune a devălmașilor pădurilor composesorale din Bucovina este destul de cunoscută în unele cercuri oficia- 
le, totuși prin faptul că nu s'a încercat - în parte cel puțin - soluționarea ei, se impune a o discuta și a preconiza măsurile de rigoare, deoarece continuarea divizării pădurilor composesorale este echivalentă cu distrugerea acestora.

\section{Formarea pădurilor composesorale și comunale.}

La ocuparea Bucovinei de către Austria așezămintele ortodoxe creștine se găseau în stăpânirea unor averi destul de mari, ce prindeau mai bine de jumătate din întinderea provinciei nord-moldovenești. Aceste averi aparțineau Episcopiei de Rădăuți, celor 14 mănăstiri și 11 schituri din Bucovina, ai căror ctitori și adăogitori erau românii și anume: domnii Moldovei, mitropoliții și episcopii, împreună cu clerul și boerii moldoveni.

Împăratul Iosif II, prin ordonanțele sale din 1781 și 1783, desființă 23 din așezămintele bisericești, menținând numai trei: Putna, Sucevița și Dragomira, iar averile mobile și imobile atât ale mănăstirilor desființate cât și ale celor menținute formară Fondul bisericesc bucovinean, a cărui constituire definitivă a avut loc deabia în 1786 prin «Regulamentul duhovnicesc». Administrația Fondului era făcută de functionarii statului.

Cum mănăstirile din Bucovina aveau în proprietate majoritatea satelor, populația acestora era obligată să lucreze pământurile Fondului bisericesc ca și mai înainte, sarcină cunoscută sub numele de robotă (boeresc) ce dădea dreptul țăranilor să beneficieze după nevoe de păşune și lemne din proprietatea acestuia.

În urma mișcării revoluționare din 1848 ce a avut în Austria un caracter agrar, au fost împroprietăriți țăranii din Bucovina, cu care ocazie Fondul bisericesc bucovinean, cel mai mare latifundiar, a cedat din proprietățile sale 80.500 ha. Pentru pământurile primite cu drept de proprietate țăranii plăteau o sumă de desdăunare Fondului bisericesc. Dar şi după împroprietărire, țăranii au păstrat drepturile ce aveau asupra pământurilor și pădurilor Fondului.

Sate întregi aveau dreptul de pășunat și de a scoate lemne pentru ars și de construcție din pădurile Fondului bucovinean. Cum aceste drepturi de servitute dădeau naștere la diferite neajunsuri, în baza patentei imperiale din $5 \mathrm{Iu}-$ lie 1853, s'a început răscumpărarea lor.

Răscumpărarea drepturilor de servitute s'a făcut prin contractele de învoială, în intervalul anilor 1854 - 1870 - când Fondul bucovinean a devenit instituţie cu administraţie proprie - și au fost aprobate de «Comisiunea pentru stingerea și regularea servituţiilor». Fondul bisericesc a cedat celor îndreptățiți o suprafață păduroasă și alte terenuri de circa 85.876 ha, precum și o sumă de 205.156 florini, iar aceștia au recunoscut dreptul de proprietate absolută și nestingherit al Fondului asupra celorlalte părți de pădure ${ }^{1}$ ).

Fiecare sat a primit câte o suprafață de pădure, cu goluri de munte și poeni, ce a variat cu numărul capilor de familie și îndrăzneala delegaților țăranilor. Contractul de învoială cuprindea numărul îndreptățiților și parcelele respective.

Odată cu introducerea cărții funduare în Bucovina, aceste proprietăți cedate de Fondul bucovinean pentru stingerea drepturilor de servitute ale îndreptățiţilor, au fost intabulate:

- o parte pe numărul de îndreptățiți (capi de familie) prevăzuți în contractul de învoială și pădurile stăpânite în devălmășie de urmașii acestora sunt pădurile composesorale de astăzi și - restul pe numele comunei respective, deși în contractul de învoială era specificat numărul îndreptățiților formând, împreună cu alte păduri dobândite ulterior, pădurile comunale.

O bună parte din pădurile zise comunale se vor transforma în păduri composesorale, deoa-

\footnotetext{
1) Datele asupra originii și înființării pădurilor composesorale le-am luat din: 1) câteva amenajamente ale ocoalelor silvice de sub administrația Fondului bisericesc bucovinean, 2) I. Nistor: Istoria Fondului bisericesc din Bucovina, 3) Ing. d-r E. Guzman: Bunurile Fondului bisericesc ortodox român din Bucovina, 4) din așezămintele câtorva composesorate, cu ocazia diferitelor anchete și inspecții ca delegat al Oficiului Național al Cooperației Române, Cernăuți.
}

172 
rece urmașii îndreptățiților îşi revendică astăzi drepturile pe cale judecătorească.

Devălmașii din comunele Moldovița, Ostra și Doroteia (toate din județul Câmpu-Lung) constituiți în obște de păduri în anul 1928, au dat în judecată comunele respective pentru stăpânirea ilicită a pădurilor ce de drept trebue să stăpânească.

În comuna Ciudei (județul Storojineț) composesoratul de pădure Ciudei și-a alcătuit aşezământul deabia în anul 1929, după ce timp de 16 ani a fost în proces cu comuna Ciudei pentru 357 ha pădure ce constituesc astăzi proprietatea în devălmășie a 225 îndreptățiți ${ }^{2}$ ).

În Bucovina, avem: 44 composesorate de pădure cu 16.850,14 ha pădure, majoritatea în județele Câmpu-Lung și Rădăuți, și 67 păduri comunele cu o suprafață de $36.884,68$ ha sau în total $54.734,82$ ha păduri composesorale și comunale ce reprezintă $12,06 \%$ din întreaga suprafaţă păduroasă a Bucovinei ${ }^{3}$ ).

După atâţia ani dela alipirea Bucovinei la patria mumă suntem nevoiți să asistăm cu durere la destrămarea acestor păduri ce-au constituit drepturi câștigate de strămoșii devălmășiilor de astăzi.

Nu este aceasta preludiul unei apropiate stări viitoare, deoarece după devastarea pădurilor composesorale urmează cele comunale cu aceeiaș origine și marea proprietate va fi chemată să satisfacă nevoile populației în lemn de foc și construcții prin sacrificarea unei mari suprafețe din domeniul său forestier?

\section{Codul silvic român în comparație cu cel austriac, nu poate împiedica divizarea pădurilor compose- sorale.}

Pădurile composesorale din Bucovina au fost constituite în baza patentei imperiale din 5 Iulie 1853 , ce cuprinde instrucțiuni privind răs- cumpărarea și regularea servituțiilor forestiere, de desărcinarea terenurilor forestiere de enclavele străine și arendarea hotarelor pădurilor.

Până în anul 1923 s'au administrat aceste păduri în conformitate cu legea provincială din 2 Iulie 1897, elaborată de guvernul local al Bucovinei în înțelegere cu dieta țării, în care erau precizate directivele pentru administrarea pădurilor comunale și composesorale din Bucovina. Administrația era încredințată administratorilor aleși de adunările generale, sau numiți de prefecturile de județ, în caz de refuz sau nereguli constatate în sarcina celor aleși.

În ce privește eșirile din indiviziune art. 5 din legea citată mai sus, stabilește că acestea se pot face în sensul art. 21 din codul silvic austriac (Forstgesetz) din 3 Decembrie 1853 care cuprinde:

«Pădurile composesorale de regulă nu se vor împărți, dacă în anumite cazuri împărțirea lor constitue o nevoe urgentă sau dacă ar oferi avantagii ce nu stau în contrazicere cu prevederile generale pentru menținerea pădurilor, in fiecare din aceste cazuri se poate permite (împărțirea lor), dar numai cu aprobarea guvernului țăriì.

Toate legile forestiere austriace cuprind dispozițiuni pentru buna administrare a acestor păduri și împiedicarea devastării lor. Deși art. 21 din codul silvic austriac face posibilă o eventuală eșire din indiviziune acest fapt nu s'a realizat în nici un loc, deoarece întotdeauna ar fi venit în contrazicere cu prevederile generale pentru menținerea pădurilor și cari ar fi prevalat.

Dela 17 Iunie 1923 - data extinderii în Bucovina a codului silvic român din 1910 și a legii modificatoare din 1920 - pădurile composesorale se administrează în conformitate cu dispozițiunile cuprinse în aceste legi.

Odată cu schimbarea legiuirilor, s'a schimbat şi soarta pădurilor composesorale deoarece le-

\footnotetext{
2) Această proprietate imobiliară a fost dobândită prin Deciziunea Comisiuni de țară pentru regularea şi degrevarea datoriilor fonciare I. R. din 28 Mai 1867sub No. 268 și predată în posesiune în baza contractului indicat la 27 D. 1970 și totuşi, la 1877 s’a trecut această avere în cartea funciară pe numele comunei politice Ciudei, ce număra foarte mulți străini.
}

3) După datele statistice ale Direcțiunei I-a silvică Cernăuți. 
gea austriacă, după cum am văzut, era categorică în privința eșirilor din indiviziune pe când cea românească face posibilă divizarea pădurilor obștenești, dacă proprietarii lor o cer ${ }^{4}$ ).

După mai puțin de patru ani dela extinderea codului silvic în Bucovina, cele mai multe păduri composesorale au fost divizate şi tăiate în bună parte. Păduri de 1.000 - 3.000 ha, aparținând composesoratelor de pădure din Vama, Pojorâta, Breaza (toate din județul Câmpu-Lung) și altele mai mici au fost divizate, n'au profitat însă decât în parte îndreptățiții, mai mult încă membrii organizatori ai divizărilor.

Divizările pădurilor composesorale din Bucovina au la bază art. 36 din Codul silvic, astfel că foarte multe păduri răzăşti au fost împărțite, ca în mai puțin de patru ani să fie tăiate aproape în întregime.

Legiuitorul român în dorința de-a asigura continuitatea pădurilor stăpânite în devălmășie și de-a stăvili devastarea celor împărțite, a formulat art. 8 din legea modificatoare din 1920 care cuprinde:

«Chiar în urma împărțelii făcută în baza art. 36 din Codul silvic, in ce privește exploatarea pădurii, starea de indiviziune continuă mai departe, iar folosința moșnenilor de venitul din exploatare va fi regulat potrivit regulelor stabilite de dispozițiunile dela art. 37 - 54 din Codul silvic».

$\mathrm{Cu}$ alte cuvinte: ieșirea din indiviziune deși are ca consecință atribuirea sau recunoașterea unor porțiuni determinate de pădure fiecărui moşnean, în proprietatea şi posesiunea sa individuală, totuşi nu-i dă dreptul să o exploateze separat de restul pădurii, de oarece starea sa de indiviziune continuă în ce privește exploatarea.

Această dispozițiune este completată de art. 20 din regulamentul pentru aplicarea legii modificatoare a codului silvic («Monitorul Ofici$a l »$ Nr. 73 din 6 Iulie 1921) care adaugă:

«Exploatarea pădurilor prevăzute în art. 8 din legea modificatoare a Codului silvic nu se poate face decât după ce moșnenii deveniți proprietari individuali, se vor constitui din nou în obște de exploatare potrivit legii silvice», dar lasă această constituire 1a latitudinea îndreptățiţilor cari trebue să o ceară.

După lege patrimoniul forestier al acestor composesorate trebue să rămână neștirbit, asigurându-se continuitatea pădurii prin amenajamentele în baza cărora se exploatează.

Şi totuși, acolo unde îndreptățiții au hotărît ieșirea din indiviziune, acestea se duc văzând cu ochii. Împotriva tuturor dispoziţiunilor legilor proprietarii nu se mai constituesc în obşte de pădure, ci se întrec în a tăia lemnul ce le-a revenit după divizare.

\section{Gauzele ieșirilor din indiviziune}

Pădurile composesorale din Bucovina a fost administrate până la război de potentații comunelor respective, cari au dispus de lemnul colectiv după voe. Starea înfloritoare a devălmașilor le impunea o atitudine de nepăsare față de actele ce gestionarii obștii făceau.

Războiul a plămădit în acești oameni o conștiință nouă, astfel că imediat au început să-și arate nemultumirea contra administratorilor composesoratelor cari nu justificau sumele cheltuite, iar obştenii nu aveau nici un profit material.

Singurii cari profitau erau evreii ce cumpăraseră,, înainte de război chiar, drepturi de pădure și cari mai mult prin contravenție au decimat în parte frumoasele păduri composesorale.

Trebue să adăogăm și criza economică, datorită căreia toți țăranii au ajuns să facă datorii mari.

Din aceste cauze tendința ca fiecare îndreptățit să intre în posesia porțiunei de pădure ce-i revine după dreptul ce are, prindea tot mai mulți aderenți, trebuia găsită modalitatea, ce a fost oferită chiar de legea silvică românească după extinderea ei în Bucovina.

Apoi topometrii și comercianții evrei - cari aveau drepturi 1a aceste păduri - pentru a gră${ }^{4}$ ) Vezi art. 36 din C. S. R.: «Împărțeala pădurilor proprietatea moșnenilor nu se poate face de cât în natură...». 174 
bi luarea hotărârilor pripite, cărora le-a urmat divizarea pădurilor. Primii destul de numeroși în Bucovina, în lipsa lucrărilor de comasare cu cari se îndeletniceau înainte de război, aveau interes să poată lucra 1a divizarea acestor păduri. Secunzii, știau că dacă obștenii vor putea intra în posesia deplină a porțiunei de pădure ce le revine, vor cumpăra lemnul cu prețuri derizorii profitând de criza economică care este permanentă.

Acești speculanți fără pagube au cutreerat satele de răzeși din Bucovina - proprietarii pădurilor obștești - îndemnându-i în sensul art. 36 din C. S. R. la divizarea pădurilor, sub motivul că tocmai acolo unde există cărți funduare (Grundbuch) și alt cod civil decât în vechiul regat, art. 8 din legea modificatoare a C. S. R. n'ar avea putere deoarece faptul trecerii în cărțile funduare a parcelelor divizate asupra proprietarului moșnean ar consfinți dreptul de liberă dispunere asupra produselor de pe acea parcelă.

Mai departe, obștenii vor putea cere pădure comunală dela Fondul bucovinean în baza «Legii pentru satisfacerea populației cu lemn» $\operatorname{din} 1924^{5}$ ).

Divizarea pădurilor composesorale fiind o afacere destul de bănoasă, pe lângă cei arătaţi mai sus, s'au grăbit să mai dea concursul și: avocați, samsari politici ce-au speculat după nevoe această chestiune, foști administratori ce aveau gestiunea neverificată, experți improvizați şi funcţionari de Stat ce şi-au asigurat prin aceasta venituri suplimentare destul de mari.

Cei chemați să supravegheze aplicarea «stricto senso» a legii sunt în primul rând judecătorii și organele silvice ale Statului. Era o datorie firească să se facă zid unic pentru salvgardarea acestor proprietăți, ce prin natura lor fac parte integrantă din patrimoniul Statului român.

\section{Jaful și debandada dela pădurile compose- sorale divizate}

\section{— Câteva tablouri de tristă realitate -}

Împărțirea pădurilor composesorale a început în anul 1924 cu composesoratul de pădure din Frumosul, care cuprinde 577,92 ha intabulate pe 107 îndreptățiţi.

Când devălmașii au cerut eșirea din indiviziune la prima adunare generală din 1924, primul care s'a sesizat a fost Directorul Regionalei silvice Cernăuți, care prin adresa Nr. 3136/924 ${ }^{6}$ ) scria între altele prim -'președintelui Curții de Apel din Cernăuți:

«S'au introdus elemente străine de obștii, cari au acaparat pe preț de nimic drepturi indivize dela țărani, prin greșelile de interpretare a judecătorilor din timpul austriac. Prin vigilența organelor de poliție silvică, pădurile acestea s'au putut însă conserva în mod destul de eficace, astfel că astăzi politica noastră trebue să fie îndreptată într'acolo, a face tot posibilul ca aceste drepturi indivize să treacă dela străini înapoi țăranilor.

Judecătoria de ocol din Câmpu-Lung, făcând uz de art. 36 al Codului silvic a admis la cererea străinilor din obște, împărțirea pădurii composesorale din Frumosul (jud. Câmpu-Lung) pădure până astăzi bine întreținută, cu o suprafață de 578 ha.

După 2 decenii, în loc de o pădure frumoasă vom avea munții goi, impănați de torenți.

Fapt este că din această împărțire nu profită decât 5 - 6 străini de neam și străini de interesele acestei țări, pe când composesorii țărani nu iau decât 1/3, 1/2, 1 sau 2 ha, pe cari în curând vor putea paște numai capre».

Bazat pe aceste considerațiuni, inspirate din adevărata dragoste pentru patrimoniul forestier, d-1 Inspector general Boldur cerea ca să se ia măsuri de către organele judecătorești pentru a se pune stavilă împărțirii pădurilor com-

${ }^{5}$ ) Așa au înțeles inginerii topometri să inducă pe țărani făcând propagandă în administrația generală din 1926 a composesoratului Părteștii de Sus, care a angajat un topometru cu 1.000 .000 lei pentru a diviza numai 360 ha pădure.

6) Dosarul composesoratului de pădure Frumosul se găsește în arhiva Direcției I-a silvică Cernăuți. 
posesorale lucru ce este egal cu desființarea lor.

Urmarea acestui apel a fost că la 31 Iulie 1924 s'a hotărît împărțirea pădurii composesoratului Frumosu, președinte al adunării fiind consilierul de tribunal din C.-Lung, care răspunde la adresa Direcțiunei silvice:

«In ce privește grija Direcțiunii generale că pădurea se va desființa în maximum două decenii, îmi lipsește darul profetic de-a profeți ce se va întâmpla în viitor. Am însă convingerea că țăranii vor păstra pădurea cum s'a întâmplat şi cu pădurile particulare, poate în mod mai eficace decât chiar obștea ca atare» ${ }^{7}$ ).

Cine a avut dreptate, ne arată evenimentele succedate.

Au început cererile pentru ca fiecare să-și tae porțiunea de pădure, pretextând mulți că vor fi nevoiți să închidă ferăstrăul ce-1 au - în imaginația lor poate - și să concedieze lucrătorii. Au venit apoi delictele silvice, tăindu-se acolo unde erau prevăzute numai extracții de arbori, sau alte parcele decât cele prevăzute, chiar rezervele, zădărnicindu-se în modul acesta regenerarea parchetelor învecinate.

Acei cari s'au dedat la devastarea pădurii Frumosu au fost cei 5 - 6 străini (Eisig Druckmann et C-nie) - îndreptățiți și ei - și cari au lucrat pentru divizarea pădurii.

Judecătorii de C.-Lung au să se pronunțe asupra peste 100 acte de contravenție pentru amenzi de 55.000 - 64.000 lei, dresate acestora din 1924 și până astăzi.

Nu s'au mulțumit cu atât: au venit cu cereri de tăeri anticipative cu motivarea: «renunțând să tăem pădurea pe anii 1927/28 și 1928/29».

Ce este mai dureros e că țăranii nu vor să împădurească și zădărnicesc lucrările de plantații ce le fac organele silvice ale Statului sub paza jandarmilor.

O altă parte tristă o constitue haosul ce domnește cu titlurile de proprietate de oarece, prin sentințele prealabile date de judecătorii, există obștea și proprietăţile individuale; acei cari se consideră divizați nu vor să mai audă de composesorat, iar cei rămaşi pe din afară tae și ei unde le vine mai bine pentru a nu rămâne fără profit.

La divizarea obștei Vama ${ }^{8}$ ) cu 2.900 ha pădure, s'au cheltuit milioane fără a se fi putut duce divizarea la bun sfârșit. Divizarea refăcându-se în baza unui plan bine stabilit, care să fie pus la dispoziția tuturor interesaților, spre a se declara în termen asupra nemulțumirilor, s'a procedat la punerea în posesie pe rând a celor îndreptățiţi, cari repede au exploatat materialele lemnoase contra tuturor opririlor şi proceselor verbale de contravenție, dresate de serviciul silvic, cari zac la judecătoria Vama.

Astăzi au rămas 30 drepturi ce nu mai pot fi plasate nefiind pădure, mai mult (procesul verbal al direcției silvice Câmpul-Lung din 1929) și 156 procese verbale de contravenție așteaptă să le vină rândul la judecătoria Vama.

Cele petrecute la composesoratele de păduri din Frumosu și Vama, s'au repetat și la alte composesorate, la fiecare din acestea, tablourile fiind tot atât de triste. Pretutindeni inegalităţi, speculări neauzite, paraziți consacrați ce-și mută sfera de activitate dela un composesorat la altul, etc.

Dintre îndreptățiţi profită doar doi, trei și aceștia sunt tot evrei, iar restul vând lemnul pe nimica, ca la urmă să vadă că n'au scăpat nici de datorie și au rămas fără pădure.

S'au instalat gatere, mișcate de motoare cu vapori, în regiuni unde n'au fost niciodată de oarece în apropierea lor sau divizat pădurile composesorale - cazul composesoratului de pădure dela Capana (Suceava) lângă gara Miron Costin - linia Dărmănești - Vatra-Dornei.

La composesoratul de pădure Moldovița (jud. Câmpul-Lung), așezământul în conformitate cu Codul silvic român a fost adoptat deabia în adunarea generală din 23 Februarie 1929, când s'a hotărât și ieșirea din indiviziune. Dealtfel lucrările pentru parcelarea pădurii şi estimarea ei s'au început din 1928. În iarna

\footnotetext{
$\left.{ }^{7}\right)$ Adresa în original se găsește la Direcția silvică Cernăuți, la dosarul composesoratului de pădure Frumosul.

${ }^{8}$ ) Hotărârea pentru eșirea din indiviziune a fost luată în adunarea generală din 21 Decembrie 1924. 176
} 
curentă s'au tăiat în contravenție peste 10.000 arbori, dresându-se actele respective.

La 1 Ianuarie 1930, din 47 composesorate de pădure, avem divizate 12 din ele, cari dețin aproape 10.000 ha pădure ce se distrug în văzul tuturor.

Tendința de divizare nu este potolită, deoarece anul acesta au mai hotărât ieșirea din indiviziune composesorii din Botoșana și Părteștii de Jos (jud. Suceava), iar cereri pentru a se lua aceleași hotărâri, se primesc la judecătorii din partea restului composesoratelor.

Conform codului silvic, la adunările generale ale composesoratelor iau parte și delegații Casei Pădurilor și ai Oficiului Național al Cooperației Române ${ }^{9}$ ). Se constată din procesele-verbale ale adunărei generale ale composesoratelor de pădure, că acești delegați au apelat la spiritul de cumințenie al obștenilor, au arătat imposibilitatea de-a dispune după voe de lemnul ce le revine, și totuși țărani n'au ținut seamă de nimic, deoarece lăsați ademeniți de luciul și sunetul talanților întinși de mâini murdare, au hotărât cu cea mai mare ușurință divizarea pădurilor.

\section{Continuarea divizărilor pădurilor compose- sorale trebue să înceteze.}

Dacă obștenii nu sunt mulțumiți cu divizarea, mulți rămân făra pădure, se cheltuesc cu parcelările tot atât cât valorează pădurea (cazul composesoratului Cacica, județul Suceava), se exploatează ca și în timpul revoluției, fiecare tăind unde poate și cât mai repede, organele silvice ale statului nu pot acționa în mod eficace, nu se pot face împăduririle, etc., aceasta se datorește legii silvice, care pentru Bucovina ${ }^{10}$ ) trebue să dispună conservarea pădurilor composesorale, fără a mai adăoga că acțiunea întreprinsă de organele silvice ale Statului și în urmă de Oficiul Național al Cooperației Române contra eșirilor din indiviziune n'a fost susținută de judecători, dar mai mult, a fost chiar combătută pe toate căile.

Schițările făcute în capitolul precedent, ilustrează suficient haosul ce domnește la composesoratele de pădure din Bucovina, pe cale de divizare.

In situația actuală:

a) Străinii exploatează ras în contravenție suprafețe mari de pădure, sub văzul autorităților silvice, deoarece știu că nu vor plăti mai mult de 5.000 lei amendă, amenda maximă prevăzută de art. 7 din Codul silvic.

b) Serviciul silvic dresează acte de contravenție, ce ajung să fie judecate tot de judecătorii ce au patronat divizările, și sentințele se tărăgănează ani de zile. Dela patru obștii de pădure din jud. C.-Lung s'au dresat 248 procese-verbale de contravenție și nu s'a dat nici o sentință, la fel la 4 obștii din jud. Rădăuți 153 procese-verbale.

c) composesoratele nu mai dispun de organele de pază.

d) ocoalele silvice n'au decât organe de control ce nu dispun de mijloace de transport.

Și cele 16.850 ha păduri composesorale vor mări în câțiva ani suprafaţa terenurilor neproductive, deoarece sunt situate pe creste cu pante repezi și divizarea lor în parcele de $1 / 2-2-3$ ha este cu totul dezastroasă pentru gospodăriile țăranilor și pentru economia țării ${ }^{11}$ ).

Divizarea pădurilor composesorale trebue să înceteze cel puţin astăzi şi nimeni altul decât legiuitorul nu poate curma acest rău, prin care păduri seculare dispar și proprietarii lor vor rămâne mai departe în sapă de lemn.

\footnotetext{
$\left.{ }^{9}\right)$ Atribuțiile Centralei Băncilor Populare au trecut asupra Oficiului Naţional al Cooperației Române, în baza art. 160 al. 2 din «Legea pentru Organizarea Cooperației» din 1929 («Monitorul Oficial» Nr. 71 din 28 Martie 1929).

${ }^{10}$ ) Argumentarea a fost făcută de d-l ing. general Zeicu, directorul Direcțiunei I-a silvică Cernăuţi, într-un memoriu citat mai sus.

${ }^{11)}$ Cifrele sunt luate dintr-un memoriu al Direcției silvice Cernăuți asupra divizării pădurilor composesorale din Bucovina, și înaintat Casei Pădurilor și Ministerului Justiției în Iulie 1929.
} 
Continuarea haosului ce s'a creiat prin divizarea pădurilor composesorale, caracterizat prin cheltueli de sume enorme și devastarea a suprafețe mari de pădure, fără a se da vre-o dare de seamă, sau a se da descărcare gestiunilor întreprinse chiar de oameni cari n'au avut căderea, grevează mult asupra legiuirilor românești în vigoare numai de 11 ani, deoarece sub dominația austriacă nu s'a divizat nici o pădure composesorală.

$\mathrm{Nu}$ trebue să lăsăm a plana asupra codului silvic român acuzația că țintește la destrămarea pădurilor stăpânite în devălmășie, atât timp cât ideia divizărilor este o nesocotință pentru cei ce o desăvârșesc și o rușine națională care n'a fost curmată până astăzi.

Dacă țăranul obștean s'a lăsat ademenit și indus în eroare de străini a contravenit la legea silvică prin tăerile ilicite și astăzi trebue să plătească valoarea materialelor înzecit, ce-1 va duce mai departe la mizerie, este o datorie imperioasă pentru forurile competinte de-a lua măsurile de îndreptare a situației pentru a se curma acest rău economic și social, fiind convinşi că cele relatate de noi în acest articol le sunt prea cunoscute.

\section{Singura soluție: intervenția legiuitorului}

Până astăzi s'au făcut numai greșeli: de interpretarea legii de procedură, abuz de prerogativele date de legi, etc.

Toate divizările au avut la bază art. 36 din Codul silvic român, ce a fost interpretat greșit $\left.{ }^{12}\right)$.

Într-adevăr, acest articol, face parte dintr'un complex de articole sub titlul, «Stabilizarea drepturilor de proprietate...» cuprinzând articolele 29 - 36, astfel că divizarea în sensul Codului silvic se poate face numai la data constituirii definitive a obștii. Că legiuitorul a dat aceeaș interpretare art. 36, reese clar din redactarea art. 8 din legea modificatoare a Codului silvic care spune: «.....chiar în împărțirea făcuta în baza art. 36 etc...» s'a referit deci, numai la împărțirile din trecut și nici decum la cele prezente sau viitoare, ce nu mai pot avea loc.

Toate memoriile făcute de direcțiunea silvică Cernăuți ca și demersurile pe lângă Ministerul Justiției, nu vor da nici un rezultat deoarece circularele prevăzute vor avea efect nul.

Singura soluție ce se poate preconiza, în situația specială a pădurilor composesorale din Bucovina, este: o lege din iniţiativă ministerială sau parlamentară care să cuprindă:

I. Abrogarea articolului 36 din Codul silvic român, ce nu-și mai are rațiunea de-a exista mai departe, atâta timp cât toate obștiile de păduri din întreaga țară sunt constituite în conformitate cu această lege.

II. Obligativitatea composesori1or ce şi-au divizat pădurile de a se constitui în obște pentru exploatare de păduri.

III. Fixarea normelor pentru readucerea composesoratelor divizate în făgaşul normal, pentru motivul că unii obșteni au tăiat mai mult decât posibilitățile anuale și în acest caz trebue să se calculeze cât material a exploatat fiecare obștean în parte, dela hotărârea ieșiri din indiviziune și până astăzi, în comparație cu dreptul de proprietate ce are și cu posibilitatea anuală a pădurii pentru a se vedea pe câți ani să fie excluşi dela produsele lemnoase.

Se va susține de mulți că această constrângere a dreptului de proprietate este în contradicţie cu caracterul acestui bun, declarat până astăzi perpetuu și intangibil. Să nu se uite însă că, de îndată ce aduce prejudicii societății, lezează ordinea socială, constitue motivul a infinite nemulțumiri și dă posibilitatea numai câtorva să se căpătuiască, în interesul general trebue să i se restrângă acest caracter consacrat până astăzi de organizația capitalistă.

"Proprietatea nu trebue să existe decât $\hat{\imath}$ măsura utilității sociale. Legiuitorul poate interveni și chiar trebue să intervină pentru a pune în concordanță proprietatea cu noua stare socială. Proprietatea nu mai este deci un

${ }^{12}$ ) Argumentarea a fost făcută de d-1 ing. general Zeicu, directorul Direcțiunei I-a silvică Cernăuți, într-un memoriu citat mai sus. 
drept intangibil şi sfânt, ci un drept continuu schimbător, care trebue să se modeleze după nevoile sociale la care răspunde»» ${ }^{13}$ ).

Dacă suntem conștienți de menirea acestor păduri, a căror dispariție duce la atacarea masivelor forestiere ale Fondului bucovinean, curmarea răului nu trebue să întârzie căci, într-un an cel mult, nu va mai rămâne nedivizată nici o pădure composesorală din Bucovina.

Menținerea pădurilor composesorale în stare de indiviziune este o binefacere pentru îndreptăţiți, deoarece le este asigurată cantitatea anuală de lemn și pădurea se menține întreagă, împădurindu-se suprafețele exploatate, lucru ce lacomii proprietari nu l-ar face.

Să rămână mai departe aceste păduri moștenite, pentru a se folosi de ele şi urmaşii, după cum strămoșii le-au păstrat intacte dela părinții lor, căci altfel ar însemna să lipsim generațiile viitoare de acest bun indispensabil. Fără intervenția legiuitorului, toate eforturile vor rămâne platonice alarmări ale funcționarilor Statului cari înțeleg să pună și suflet în însărcinările ce au.

$\left.{ }^{13}\right)$ S. Alexeanu: «Tratat de drept internațional». 